\title{
KEPENTINGAN ARAB SAUDI MEMBERIKAN BANTUAN MILITER DALAM PERANG SAUDARA DI YAMAN \\ TAHUN 2015-2019
}

\author{
Yulia Rimapradesi \\ Universitas Muhammadiyah Yogyakarta \\ yuliarimapradesiumy@gmail.com
}

\begin{abstract}
ABSTRAK
Penelitian ini dibuat untuk mengatahui kepentingan Arab Saudi memberikan bantuan militer dalam perang saudara di Yaman pada 2015 hingga 2019. Perang saudara di Yaman merupakan konflik berkepanjangan yang terjadi atas Gerakan kelompok Al-Houthi melawan kelompok pemerintahan Yaman untuk merebut kekuasaan. Konflik yang melanda Yaman selama bertahun-tahun mengakibatkan krisis dan goyahnya sistem politik. Atas permintaan bantuan dari Presiden Hadi untuk memulihkan kekuasaannya di Yaman, Arab Saudi terlibat dengan mengirimkan bantuan militer dengan jumlah yang tidak sedikit. Tentunya bantuan tersebut bukan hanya atas dasar kemanusiaan. Arab Saudi meniliki kepentingan dalam memberikan bantuan militer tersebut, seperti keamanan perbatasan, politik ideologi dan ekonomi.
\end{abstract}

Kata kunci: Bantuan militer, keamanan perbatasan, politik ideologi, ekonomi.

\begin{abstract}
This research was made to know the interests of Saudi Arabia to provide military assistance in the civil war in Yemen in 2015 to 2019. The civil war in Yemen is a prolonged conflict that occurred over the Al-Houthi Movement against Yemeni government groups to seize power. Conflicts that have plagued Yemen for years have resulted in crises and a political system that has faltered. At the request of President Hadi's help to restore his authority in Yemen, Saudi Arabia was involved in sending military assistance in an insignificant amount. Of course, this assistance is not only on the basis of humanity. Saudi Arabia has an interest in providing military assistance, such as border security, ideological and economic politics.
\end{abstract}

Keywords: Military assistance, border security, ideological politics, economy.

\section{PENDAHULUAN}

Militer merupakan penggunaan angkatan bersenjata untuk menyelesaikan konflik yang terjadi di negara lain. Sepanjang sejarah, militer sering digunakan untuk membantu suatu negara dalam melindungi atau memperluas wilayah atau kedaulatannya. Menggunakan kekuatan untuk mencampuri urusan negara lain dengan cara yang mempengaruhi kontrol 
bangsa itu atas wilayah atau populasinya merupakan cara klasik bagi setiap negara. Selama 40 tahun terakhir, Perserikatan Bangsa-Bangsa dan beberapa negara barat seperti Amerika Serikat, Inggris, dan Perancis, telah menggunakan militer untuk campur tangan dengan memberikan bantuan atau perlindungan selama masalah ekonomi, pelanggaran hak asasi manusia, dan pemberontakan politik di seluruh dunia (Jones, 2019).

Keterlibatan Arab Saudi pada perang saudara di Yaman sangat intens pada Maret 2015. Dimana pada saat itu Presiden Abduh Rabbuh Mansur Hadi sebagai presiden Yaman mengundurkan diri dari jabatannya karena dianggap lemah dan korup. Namun tak lama berselang Presiden Hadi mencabut pengunduran dirinya setelah melarikan diri ke Aden dan menjadikan Aden sebagai ibukota sementara bagi Yaman (Asmardika, 2015). Kemudian, Presiden Abduh Rabbuh Mansur Hadi meminta bantuan untuk memulihkan kekusasaannya di Yaman dengan mengirim surat kepada Arab Saudi dan Negara Teluk lainnya. Arab Saudi menyetujui permintaan bantuan tersebut. Arab Saudi dan Negara Teluk lainnya mengirimkan pesawat tempur untuk melancarkan serangan udara kepada Al - Houthi dan sekutu yang mengancam akan menyerbu pelabuhan selatan Aden (Kirkpatrick, 2015).

Al - Houthi sendiri merupakan kelompok yang bertolak belakang dengan paham kelompok pemerintahan Presiden Hadi. Al - Houthi sendiri memiliki pemahaman Syiah yang bertentangan dengan Monarki Negara - Negara Teluk terutama Arab Saudi yang beraliran Sunni. Al - Houthi memulai pemberontakan pada tahun 2004 melalui dukungan pemuka dan pemimpin agama dan tokoh sentral di kawasan utara Yaman. Ketika gelombang revolusi Arab 2011, pemerintahan Presiden Ali Abdullah Saleh berhasil ditumbangkan oleh Al-Houthi setelah 33 tahun memerintah. Setelah itu, Al - Houthi memperluas wilayah kekuassaannya dari Saada, Amran, hingga ke ibukota yaitu Saana. Pada Agustus 2014 Al Houthi menuntut pemerintah Yaman yang baru yaitu Presiden Abduh Rabbuh Mansur Hadi untuk menurunkan harga bahan bakar minyak dan menghentikan beberapa orang dalam pemerintahannya. Lalu menggantinya dengan faksi-faksi dari perwakilan Al - Houthi yang ada di Yaman yang kemudian di setujui oleh Presiden Hadi. Namun tak berselang lama terjadi gencatan senjata antara militer $\mathrm{Al}$ - Houthi dengan militer Yaman yang menyebabkan memanasnya konflik di negara tersebut (Agestu, 2014).

Konflik antara $\mathrm{Al}$ - Houthi dan kelompok pemerintah ini mengakibatkan kericuhan dan banyaknya korban berjatuhan. Stabilisasi di Yaman menjadi semakin tidak menentu. Hingga pada 21 September 2014, kedua kelompok ini mengadakan rekonsiliasi yang dihadiri oleh Penasehat Perserikatan Bangsa - Bangsa untuk Yaman. Perjanjian rekonsiliasi tersebut 
berisi tentang penentuan pembentukan dalam waktu tiga hari untuk pemerintahan baru. Kemudian Presiden Mansur Hadi memilih perdana menteri dri non-partisan pemerintah untuk memimpin pemerintahan, menurunkan harga BBM, dan sebagai gantinya, Houthi akan menarik mundur pasukan militernya dari Saana, serta melakukan gencatan senjata untuk pertempuran antara tantara Al-Houthi dengan militer di wilayah Utara. Namun Al Houthi menolak menandatangani hal tersebut hingga keadaan semakin rumit dan terus menerus terjadi perselisihan diantara keduanya (Agestu, 2014).

Pada 7 Oktober 2016, Arab Saudi melakukan serangan udara dalam acara pemakaman di Saana yang menewaskan lebih dari 140 orang. Saudi melakukan hal tersebut untuk mendukung kelompok Presiden Hadi atau pemerintah Yaman yang resmi setelah istana kepresidenan di Yaman telah diambil Alih oleh Houthi. Dari data PBB sepanjang 2017 juga lebih dari 8.800 warga Yaman tewas dan lebih dari 51.000 lainnya mengalami luka akibat dari serangan jet - jet tempur Arab Saudi yang hampir setiap hari membombardir Yaman (ParsToday, 2018).

Koalisi Arab Saudi kembali melancarkan serangan besar - besaran pada Juni 2018 menggempur kota pelabuhan utama kelompok pemberontak Houthi di Hudaidah udara dan darat dengan bantuan jet tempur serta kapal perang Saudi yang mengawal pasukan tentara Yaman di sebelah selatan Hudaidah. Medan pertempuran tersebut memiliki luas sepanjang 10 kilometer dari dekat bandara Hudaidah hingga al-Duraymi. Hal tersebut dilakukan Arab Saudi karena berupaya mengambil alih kembali bandara, pelabuhan, dan juga jalur menuju ibu kota Sanaa. PBB (Perserikatan Bangsa - Bangsa) mencatat pada akhir 2018 sekitar 56.000 orang tewas akibat perang saudara ini (CNN Indonesia, 2018).

Hingga terakhir pada 20 September 2019, koalisi yang dipimpin Arab Saudi melakukan operasi militer ke kota pelabuhan utara Yaman dan menghancurkan sekitar empat situs Hudaidah yang digunakan untuk merakit kapal dan ranjau laut kendali jarak jauh. Arab Saudi beralasan operasi ini bertujuan untuk mengamankan navigasi maritim di wilayah tersebut. Dan kelompok Al - Houthi menyebut bahwa koalisi Arab Saudi telah melanggar kesepakatan PBB di Swedia (Perdana, 2019).

Bila dilihat dari segi politik, perang saudara di Yaman dapat diartikan sebagai perpecahan dalam entitas politik. Dan seharusnya merupakan lingkup yang harus di selesaikan oleh Yaman secara nasional. Namun atas permintaan Presiden Hadi Arab Saudi bersedia menjadi pemasok dan pendukung kekuatan kelompok Presiden Hadi dalam perang 
saudara di Yaman. Dengan memberikan bantuan militer sebenarnya juga bukanlah hal yang positif bagi image Arab Saudi dimata Internasional. Lalu apa yang membuat Arab Saudi rela mengirimkan bantuan militer secara besar - besaran ke Yaman sebagai sekutu Hadi. Penelitian ini akan menjelaskan mengapa Arab Saudi memberikan bantuan senjata kepada kelompok Presiden Hadi dalam perang saudara di Yaman. Akan dijelaskan dari beberapa aspek, baik itu keamanan, politik, ataupun ekonomi.

\section{KERANGKA PEMIKIRAN}

\section{Konsep Bantuan Militer}

Bantuan militer merupakan bagian dari bantuan luar negeri yang didefinisikan dengan pemberian atau transfer suatu bantuan baik itu ekonomi, kemanusiaan, teknik, medis dan sebagainya dari pihak yang berada di luar dari negara yang membutuhkan bantuan tersebut. Bantuan luar negeri merupakan program yang diperlukan untuk membantu negara - negara miskin untuk memperoleh modal dan teknologi baru (O'Callaghan, 2002).

Teori ketergantungan (dependensia) berpendapat bahwa bantuan luar negeri digunakan oleh negara kaya untuk mempengaruhi hubungan dan luar negeri negara penerima bantuan, menarik simpati elit politik dengan tujuan komersil dan keamanan nasional. Melalui jaringan internasional, keuangan internasional dan struktur produksi bantuan tersebut dapat ditujukan untuk eksploitasi sumber daya alam negara penerima bantuan. Sehingga penganut teori dependensia menganggap bahwa bantuan luar negeri dalam bentuk apapun, termasuk bantuan militer yang digunakan sebagai alat untuk perlindungan dan ekspansi negara kaya ke negara miskin yang menjadi sebuah cara untuk menguatkan ketergantungan (Yani, 2014).

Menurut Pearson dalam bukunya menyatakan realisme berpendapat bahwa, aspirasi abstrak kemanusiaan bukanlah hal yang menunjukkan tujuan utama bantuan luar negeri. Tetapi untuk proyeksi power nasional dan bantuan luar negara menjadi komponen penting dalam kebijakan keamanan internasional (Pearson, 1999).

K.J Holsti membuat bantuan luar negeri terbagi menjadi empat jenis, yaitu bantuan militer, bantuan teknik, Grant dan program komoditi impor, dan pinjaman pembangunan. Batuan luar negeri secara bilateral memiliki ikatan politik yang lebih kuat dengan kepetingan yang lebih spesifik, sedangkan bantuan luar negeri yang bersifat multilateral lebih luas secara kepentingan dikarenakan banyaknya negara terlibat di dalamnya (Yani, 2014).

Terda pat juga empat motivasi dalam pemberian batuan luar negeri, yaitu 
- Kemanusiaan, yang bertujuan untuk mengurangi kemisikinan di negara ketiga atau negara yang membutuhkan melalui bentuan ekonomi.

- Politik, yaitu bertujuan untuk memperbagus image negara pemberi bantuan dikancah internasional.

- Keamanan nasional yang berasumsi bahwa bantuan luar negeri akan meningkatkan stabilitas politik dan ekonomi yang nantinya akan memberikan keuntungan ekonomis bagi negara pemberi bantuan.

- Segala hal yang berkaitan dengan kepentingan nasional negara pemberi bantuan (Yani, 2014).

Negara yang berkonflik berkepanjangan seperti Yaman akan mengalami goncangan terutama dalam bidang ekonomi. Banyak terjadi kelaparan dan krisis kemanusiaan lainnya. Maka sangat dimungkinkan bantuan luar negeri dari negara kaya seperti Arab Saudi untuk masuk. Terutama berupa bantuan militer bagi kelompok Presiden Hadi untuk melawan Houthi.

Motif keamanan nasional dapat dikaitkan menjadi salah satu motivasi bagi Arab Saudi untuk memberikan bantuan militer kepada kelompok Presiden Hadi dalam perang saudara di Yaman. Dimana motif ini berasumsi bahwa untuk dapat menghasilkan pertumbuhan ekonomi dan kestabilan politik yang nantinya akan memberikan keuntungan pada kepentingan negara pemberi bantuan maka bantuan militer menjadi instrumen yang tepat karena sebenarnya motif keamanan memiliki sisi ekonomis.

Kemudian motif kemanusiaan, sebagai negara yang menganut aliran Sunni, Arab Saudi merasa bertanggung jawab atas saudara dan lebih tepatnya terhadap kelompok Presiden Hadi yang ada di Yaman. Tujuan pemberian bantuan luar negeri lainnya untuk mendukung pesekutuan. Pihak pemberi bantuan yang tidak memperhitungkan persayaratannya selalu mengharapkan keuntungan jangka panjang yang tidak dapat diperoleh secara penuh melalui diplomasi. Maka dapat dikaitkan bahwa, bantuan militer yang dilakukan oleh Arab Saudi berkemungkinan besar menuju kestabilan politik dan ekonomi kedepannya bagi Yaman maupun Arab Saudi dan negara di kawasan Teluk lainnya.

\section{Konsep Kepentingan Nasional}

Salah satu pendekatan yang dominan dalam Hubungan Internasional untuk merujuk kepada kepentingan nasional yaitu Realisme. Sering disebut juga dengan Power Politic, 
pemikiran ini populer diantara pemikiran akademik maupun pemikiran para pembuat keputusan dan diplomat (Wijatmadja, 2016).

E.H Carr dalam International Relation Between The Two World War (1945) pemikirannya digunakan sebagai rujukan bagi realisme menjelaskan bahwa unsur utama dalam politik internasional adalah kekuasaan (power). Yang terdiri dari tiga unsur penting, yaitu kekuatan militer, kekuatan ekonomi, dan kekuatan untuk mempengaruhi yang berperan penting dalam menjaga keberlangsungan suatu negara (Hadiwinata, 2017).

Morgenthau pada bukunya tentang Politic Among Nation, The struggle for power and peace, menjelaskan bahwa power merupakan suatu hubungan antara dua aktor politik yaitu negara. Dimana dalam studi kasus ini Arab Saudi memiliki kemampuan untuk mengontrol atau megendalikan pemikiran atau tindakan Yaman. Jadi menurut Morgenthau power dapat terdiri dari apa saja yang meliputi seluruh hubungan sosial mulai dari kekerasan fisik sampai dengan hubungan psikologis yang halus (pengendalian pikiran) (Thompson, 1985).

Morgenthau berpendapat, dalam bernegara pasti memiliki banyak lingkup kepentingan, diantaranya kepentingan nasional dan kepentingan regional. Dan bagi Morgenthau kepentingan nasional melupakan hal terpenting karena hal tersebut yang mendahului sebelum kepentingan regional. Maka dari itu, memiliki aliansi haruslah yang memiliki manfaat yang berlandaskan keuntungan dan keamanan timbal-balik bagi negara peserta bukan pada ikatan-ikatan ideologis atau moral.

Kepentingan nasional adalah kepentingan negara yang dijalankan oleh pembuat keputusan terhadap negara lain dalam rangka merealisir agenda-agenda yang telah ditentukan sebelumnya. Kepentingan nasional terbagi atas dua kategori yaitu kepentingan praktis atau jangka pendek yang artinya kepentingan suatu negara yang mendesak yang berhubungan dengan eksistensi kehidupannyanya dan bersifat seketika. Kemudian kepentingan kontinuitas atau jangka panjang merupakan kepentingan nasional yang diperoleh atas kontak dengan negara lain yang bersifat berkelanjutan dan nantinya memiliki efek jangka bagi keuntungan negaranya.

Selanjutnya hubungan kekuasaan dengan relasi power akan menjadi jalan untuk mewujudkan kepentingan nasional suatu negara. Kepentingan Nasional menurut kamus Hubungan Internasional merupakan cita - cita yang perlu diperjuangkan untuk mewujudkan kebutuhan bangsa sendiri demi tercapainya tatanan kehidupan bernegara yang sejahtera, adil dan makmur. (Elzabar, 2012).

Terdapat 5 kategori umum yang dijadikan sasaran dalam kepentingan nasional yaitu : (1) self-preservation, yaitu hak untuk mempertahankan diri, dimana setiap negara berhak untuk 
menjaga dirinya dari berbagai kemungkinan ancaman yang akan mengganggu kestabilan negara; (2) independence, yang berarti tidak dijajah atau tunduk pada negara lain, setiap negara berhak untuk merdeka dan sudah merupakan hak nya sebagai negara dan juga dimana negara tidak untuk patuh terhadap negara lain; (3) territorial integrity, negara berhak untuk menjaga keutuhan wilayah atau teritorial negaranya; (4) military security, berarti tidak ada gangguan dari kekuatan militer negara lain, dengan kata lain tidak ada ancaman secara militer yang datang dari negara lain; (5) economic well-being, atau dapat disebut kesejahteraan ekonomi, sektor ekonomi harus selalu dijamin kesetabilannya oleh pemerintah agar tercipta kesejahteraan di negara tersebut.

Fungsi dari kepentingan nasional sendiri sebagai unsur landasan atau patokan para pemimpin dalam melakukan hubungan luar negeri dan untuk mengevaluasi kinerja pemerintah dalam melakukan interaksi di dunia internasional. Morgenthau berpendapat bahwa kepentingan nasional merupakan alat untuk mengejar kekuasaan, karena melalui kekuasaan itulah suatu negara dapat mengontrol negara lain dan untuk melindungi dan mempertahankan identitas fisik, politik, dan kultur dari gangguan negara lain (Ronapea, 2016).

Dari latar belakang masalah, Arab Saudi memberikan bantuan bukanlah serta merta berbicara tentang kemanusian saja. Dalam perang saudara di Yaman terbentuk dua kubu dengan aliansi masing - masing. Dimana Iran terlibat dengan kubu lawan yaitu Houthi. Iran dan Arab Saudi merupakan negara rival dikawasan Teluk. Arab Saudi memiliki tiga kepentingan dalam konflik ini, yaitu politik militer dengan keamanan perbatasan, politik ideologi dan ekonomi. Bukan rahasia besar jika Yaman merupakan negara yang kaya akan minyak. Jika Arab Saudi dapat mengukuhkan kekuasaan Presiden hadi hal tersebut akan sangat menguntungkan dalam melakukan lobi di perbatasan. Dari segi ekonomi, Arab Saudi ingin mempertahankan dan memastikan keamanan selat Hormuz, karena jika Houthi Bersama Iran memiliki kekuatan diwilayah tersebut akan menghambat lalu lintas terutama jalur ekspor minyak dari Arab Saudi. Dengan relasi power, akan terbentuk perimbangan kekuatan melalui bantuan militer ke Yaman. Maka tidak ada yang salah jika Arab Saudi juga memiliki kepentingan untuk menahan hegemoni Iran dan perimbangan kekuatan di wilayah Teluk (Saraswati, 2017). 


\section{Teori Ideologi}

Tradisi Marxis memandang ideologi sebagai kesadaran yang terdistorsi, merefleksikan realitas material yang eksploitatif, yang dapat diatasi dengan membuka kedoknya atau, barubaru ini sebagai narasi fiktif yang diperlukan untuk menjaga tatanan sosial. Pendekatan nonMarxis terbagi menjadi tiga perspektif. Yang pertama melihat ideologi sebagai abstrak, tertutup dan doktriner, sebagian besar tahan terhadap bukti empiris dan ditumpangkan pada masyarakat. Yang kedua melihat ideologi sebagai serangkaian sikap yang secara empiris dapat dipastikan terhadap isu-isu politik yang dapat dieksplorasi dengan menggunakan metode perilaku. Yang ketiga memandang ideologi sebagai alat pemetaan yang sangat diperlukan dari simbol budaya dan konsep politik yang merupakan sumber daya penting untuk memahami dan membentuk kehidupan sosial politik. Mereka bersaing atas makna kata-kata dan ide-ide politik yang 'benar' dan sah, dan melalui kontrol itu, di atas dataran tinggi politik (Freeden, 2001).

Karl Marx dianggap yang pertama memberikan kerangka teoretis ideologi dalam konteks sosiologi. Pendekatan Marx terhadap ideologi dituangkan dalam teorinya tentang landasan dan struktur. Menurut Marx ideologi merupakan, "Production of Ideas, of conceptions, of concioussness, all that men say, imagine, conceive" dan di dalamnya dijelaskan bentuk asli dapat dilihat dalam politisasi ide, hukum-hukum dalam kehidupan manusia, agama yang tercipta, mau pun segala jenis metafisika. Suprastruktur masyarakat, ranah ideologi, tumbuh dari pangkalan, ranah produksi, untuk mencerminkan kepentingan kelas penguasa dan membenarkan status quo yang membuat mereka tetap berkuasa. Marx, kemudian memfokuskan teorinya pada konsep ideologi dominan. Namun, ia memandang hubungan antara basis dan superstruktur sebagai sifat dialektis, yang berarti bahwa masingmasing memengaruhi yang lain secara setara dan bahwa perubahan dalam satu memerlukan perubahan yang lain. Keyakinan ini menjadi dasar bagi teori revolusi Marx. Dia percaya bahwa begitu para pekerja mengembangkan kesadaran kelas dan menyadari posisi mereka yang dieksploitasi relatif terhadap kelas yang kuat dari pemilik dan pemodal pabrik - dengan kata lain, ketika mereka mengalami perubahan mendasar dalam ideologi - bahwa mereka kemudian akan bertindak berdasarkan ideologi itu dengan mengorganisir dan menuntut perubahan dalam struktur sosial, ekonomi, dan politik masyarakat (Cole, 2019).

Dalam studi kasus ini, ideologi Arab Saudi yang memiliki pemahaman Sunni sebagai kekuatan muslim terkemuka menjadi hal yang sangat dipertahankan. Perseteruan yang sudah berlangsung beberapa dekade di antara Saudi dan Iran sebagian besar Muslim Syiah. 
Sepanjang terjadinya konflik, Iran sebagai sekutu Houthi merupakan ancaman bagi Arab Saudi, jika terjadi demokratisasi di Yaman dan Iran sebagai negara yang sangat berpengaruh memberi dukungan terhadap Houthi hal tersebut akan mengancam eksistensi Arab Saudi di kawasan Teluk dan Timur tengah.

\section{METODE PENELITIAN}

\section{Metode Pengumpulan Data}

Metode pengumpulan data dalam penelitian ini menggunakan metode kualitatif, yang bersifat menekankan pada pemahaman mengenai masalah kehidupan sosial berdasarkan kondisi realitas yang subyektif dan berdimensi banyak. Dengan mengandalkan teknik library research atau penelitian kepustakaan. Data yang diperoleh merupakan data sekunder yang valid yang diperoleh dari beberapa buku, e-jurnal, media online, majalah, dan dokumen-dokumen (Jatmika, Skripsi : Metodologi dan Romantikanya, 2016).

\section{Metode Analisa Data}

Metode Analisa pada tulisan ini merupakan teknik analisa induktif atau dengan memahami fakta digunakan dalam penelitian ini. Diawali dengan mengumpulkan fakta fakta dari objek yang berkaitan kemudian fakta - fakta tersebut diubah menjadi general empiris, dan kemudian melalui general empiris dapat dilakukan perumusan konsep, merangkai preposisi dan diubah untuk menjadi induksi teori (Mas'oed M. , 1990).

\section{HASIL PENELITIAN}

\section{Politik Luar Negeri dan Kapabilitas Militer Arab Saudi}

Politik luar negeri Kerajaan Arab Saudi dibagi menjadi empat kawasan, yaitu kawasan teluk, negara-negara Arab, Islam, dan internasional. Di kawasan teluk, Arab Saudi memberikan perhatian khusus karena kesamaan dan kedekatan satu sama lain. Kedekatan tersebut berupa kedekatan wilayah, hubungan darah, dan kedekatan secara sejarah. Fokus perhatian wilayah politik luar negeri kedua adalah negara-negara Arab. Pengikat utamanya adalah konflik Palestina, yang berupa semangat persaudaraan sehingga menyebabkan Arab Saudi tidak bias lepas dari kawasan negara-negara Arab (Cipto, 2011). 
Perioritas Islam sebagai politik luar negeri Arab Saudi menjadi fokus ketiga. Karena Islam tidak hanya menciptakan ikatan antara negara tetangga dan negara Arab lainya. Dengan Islam, Arab Saudi mewujudkan hubungan lebih luas dengan negara-negara Islam, atau yang bermayoritaskan Islam di dunia. Didukung dengan adanya dua kota Suci Umat Islam yaitu Mekkah dan Madinah yang menjadi pusat peribadahan muslim dunia. Sebagai negara yang merupakan tempat awal mula sejarah islam Arab Saudi merasa bertanggung jawab khusus untuk menjadikan Islam sebagai tema sentral politik luar negerinya. Sikap anti-komunis juga menjadi salah satu implikasi dari politik luar negeri Arab Saudi. Sikap ini melekat kuat pada para pemimpin Arab Saudi yang dibuktikan juga dengan tidak dibukanya hubungan diplomatik dengan Uni Soviet selama puluhan tahun (Cipto, 2011).

Yang terakhir adalah secara lingkup Internasional, sama seperti negara lain. Arab Saudi juga menjalin kerjasama terhadap negara - negara non-muslim, seperti amerika serikat, negara-negara Uni Eropa, kawasan Afrika, Asia, hingga Australia. Faktor kawasan Timur Tengah yang sangat rawan konflik mengakibatkan sangat dibutuhkannya kerjasama yang luas untuk meningkatkan rasa aman.

Dalam dunia hubungan internasional saat ini, hubungan antar negara tidak lagi hanya secara bilateral. Hubungan multilateral dengan adanya organisasi internasional saat ini sangat berkembangan demi mewujudkan kepenting dan cita-cita internasional. Organisasi internasional terbagi dalam 2 jenis yaitu, Intergovemental Organizations (IGO's) dan International Non-Governmental Organizations (INGO's). Beberapa analisis dan praktisi berpendapat bahwa organisasi internasional dipahami untuk menjalankan fungsi-fungsi penting dalam system negara, sebagai alat administratif untuk mengubah kebijakan menjadi aksi, dan sebagai penyalur atau saluran pengakomodasian pemerintah untuk dapat mengekspos kepentingan masing-masing dan sebagai wadah penyelesaian masalah (Sugito, 2016).

Pada 2017, Arab Saudi merupakan raksasa regional yang anggaran militernya sebesar 76,7milyar Dollar AS menempatkan dirinya dalam posisi kelima di negara Teluk menurut Global Fire Power. Keterlibatannya dalam perang saudara Yaman selama beberapa tahun terakhir telah memberikan pasukannya pengalaman garis depan yang berharga, kegagalan dalam mengalahkan Houthi pada perang Yaman telah menimbulkan pertanyaan tentang seberapa efektif kekuatan tempur militer yang dimiliki Arab Saudi sebenarnya (Dubley, 2018). 
Menurut sistem ranking Global Fire Power pada tahun 2019, Arab Saudi menduduki peringkat ke 25 dari total kekuatan militer dari 137 negara dunia dengan power indeks 0,4286 (0,0000 adalah titik sempurna). Dengan populasi penduduk sekitar 33 juta jiwa, Arab Saudi memiliki 230 ribu total personil aktif dan tidak ada personil cadangan (Global Fire Power, 2019).

Pemerintah Arab Saudi juga membuat kebijakan baru di tahun 2019 dimana pemerintah menyatakan bahwa perempuan dapat mulai bekerja di militer, dimana sebelumnya mereka hanya bisa bekerja di kepolisian. perempuan akan dapat bergabung sebagai kopral tombak, kopral, sersan dan sersan staf di Angkatan Darat Kerajaan Saudi, Angkatan Udara Saudi, Angkatan Udara Saudi Arabia, Pertahanan Udara Saudi Arabia, Angkatan Rudal Strategis Saudi Arabia, Angkatan Rudal Strategis Saudi dan Angkatan Bersenjata Layanan Medis Pasukan (Khaleejtimes.com, 2019).

The Saudi Arabian Armed Forces (SAAF) atau yang disebut juga dengan angkatan bersenjata Kerajaan Arab Saudi merupakan pasukan militer Arab Saudi yang bertanggung jawab untuk pertahanan yaitu Angkatan Darat, Angkatan Laut, Angkatan Udara, Pertahanan Udara, dan di bawah Kementrian Pertahanan dan Penerbangan.

Berdasarkan data SIPRI pada 2018, total dari pembelian senjata dari kelima negara eksportir tersebut dari tahun 2014 hingga 2018 adalah \$ 15,6 Triliun. Amerika Serikat terus memasok sebagian besar senjata ke Saudi, terhitung 88 persen dari semua senjata yang dijual ke Arab Saudi. Pada 2014 hingga 2018, Arab Saudi menerima 22 persen dari ekspor senjata AS termasuk senjata utama, seperti kendaraan lapis baja, peluru kendali, pesawat terbang, artileri dan kapal. Kemudian Arab Saudi juga menerima pengiriman pesawat tempur sebanyak 38 unit dari Inggris, yang dilengkapi dengan rudal jelajah dan senjata berpemandu lainnya. Lalu pengiriman senjata berikutnya yang direncanakan untuk 2019 hingga 2023 adalah 98 pesawat tempur, tujuh sistem pertahanan rudal dan 83 tank dari AS, 737 kendaraan lapis baja dari Kanada, lima fregat dari Spanyol dan rudal balistik jarak pendek dari Ukraina (Chughtai, 2019).

\section{Bantuan Militer Arab Saudi dalam Perang Saudara di Yaman}

Arab Saudi memiliki keterlibatan sangat intens pada Maret 2015. Ketika Presiden Abduh Rabbuh Mansur Hadi meminta bantuan untuk memulihkan kekusasaannya di Yaman dengan mengirim surat kepada Arab Saudi dan Negara Teluk lainnya seperti, Oman, Kuwait, Qatar, 
Uni Emirat Arab, dan Bahrain. Surat terbuka menceritakan kondisi Yaman yang tidak setabil akibat serangan dari kelompok Al Houthi yang dilakukan secara terus-menerus dengan sasarannya termasuk warga sipil Yaman. Kemudian Presiden Hadi juga menceritakan kondisi terkini saat itu dimana, Al Houthi mulai bergerak ke arah selatan yaitu bagian kota Lahj da Aden ibukota darurat yang menjadi tempat Presiden Hadi.

Kutipan surat terbuka Presiden Hadi kepada pemimpin-pemimpin negara Teluk: "Berdasarkan hal di atas, saya mengharapkan kepada Anda semua wahai saudara-saudaraku, mengharapkan bantuan dari Negara-negara Anda semua untuk berada di pihak rakyat Yaman dalam rangka menjaga Negara Yaman. Saya meminta kepada Anda semua dengan berdasarkan pada prinsip-prinsip mempertahankan diri yang tertuang dalam pasal 51 dari Piagam PBB, berdasarkan pada dasar Piagam Liga Arab dan Perjanjian pertahanan wilayah Arab secara bersama-sama, untuk segera memberikan bantuan dan dukungan dengan segala hal-hal yang diperlukan, termasuk intervensi militer untuk melindungi Yaman dan rakyatnya dari agresi yang terus menerus dilakukan oleh kelompok pemberontak Houthi dan mencegah terjadinya serangan yang mungkin saja terjadi di setiap waktunya di kota Aden dan wilayahwilayah selatan. Dan kami meminta juga meminta bantuan dalam menghadapi al-Qaeda dan Islamic State" (Firdaus, 2017).

Hingga pada 26 Maret 2015 Arab Saudi dan negara - negara Teluk lainnya dipimpin oleh Raja Salman menyetujui permohonan Presiden Hadi dengan mengirimkan ratusan ribu tantara dan kendaraan tempur ke dalam kota Sanaa untuk memerangi pasukan Al-Houthi. Arab Saudi mengirimkan 100 pesawat tempur dan 150.000 tentara untuk operasi militer. Royal Saudi Air Force mengambil alih pertahanan udara Houthi dengan mengamankan sebagian besar wilayah udara Yaman dan sedang mengkonsolidasikan zona larangan terbangatau no-fly zone yang luas. Dan Arab Saudi juga menghancurkan banyak pesawat tempur milik Houthi. Keesokan harinya, pada 27 Maret 2015 kapal perang Arab Saudi bersama dengan Mesir sebanyak skuadron juga telah tiba di selat Bab el Mandeb untuk mengamankan wilayah tersebut yang dianggap sebagai jalur transportasi pengiriman senjata dari Iran untuk Al-Houthi dan sebagai jalur pengiriman minyak dari ataupun keluar Yaman. Pada 12 April, Arab Saudi kembali meluncurkan serang udara ke pangkalan Brigade ke-22 Pengawal Republik Yaman di lebih tepatnya di pusat perkantoran Gubernur Taiz (Hanna, 2015). 
Pada 26 April 2015 Arab Saudi mengirimkan pesawat tempur F-15 untuk membombardir bandar udara di Saana demi mencegah pesawat Iran yang diduga membawa pasokan senjata Houthi, seperti yang kita ketahui bahwa Iran dan Houthi menjadi sekutu dalam perang saudara di Yaman ini. Pada 8 September 2015 pasukan pimpinan Saudi dikerahkan ke Yaman dengan jumlah lebih dari 10.000 pasukan dan 30 helikopter serang AH-64 Apache (Reuters, 2015).

Pada 7 Oktober 2016, Arab Saudi melakukan serangan udara dalam acara pemakaman di Saana yang menewaskan lebih dari 140 orang. Saudi melakukan hal tersebut untuk mendukung kelompok Presiden Hadi setelah istana kepresidenan di Yaman telah diambil Alih oleh Houthi. Awal tahun 2017 tekanan pertempuran antara Al- Houthi dan kelompok Presiden Hadi meningkat di sepanjang pantai Laut Merah. Meskipun pemboman udara besar-besaran dilakukan oleh koalisi yang dipimpin Saudi, kelompok Al-Houthi tetap memegang kendali atas provinsi-provinsi utama tengah dan utara seiring dengan tekanan yang meningkat pada Al-Houthi di al-Bayda, Saada, dan al-Jawf. Dari data PBB sepanjang 2017 juga lebih dari 8.800 warga Yaman tewas dan lebih dari 51.000 lainnya mengalami luka akibat dari serangan jet - jet tempur Arab Saudi yang hampir setiap hari membombardir Yaman (ParsToday, 2018).

Koalisi Arab Saudi kembali melancarkan serangan besar - besaran pada Juni 2018 menggempur kota pelabuhan utama kelompok pemberontak Houthi di Hudaidah. Dengan bantuan jet tempur serta kapal perang Saudi yang mengawal pasukan tentara Yaman di sebelah selatan Hudaidah. Medan pertempuran tersebut memiliki luas sepanjang 10 kilometer dari dekat bandara Hudaidah hingga al-Duraymi. Hal tersebut dilakukan Arab Saudi karena berupaya mengambil alih kembali bandara, pelabuhan, dan juga jalur menuju ibu kota Sanaa. PBB (Perserikatan Bangsa - Bangsa) mencatat pada akhir 2018 sekitar 56.000 orang tewas akibat perang saudara ini (CNN Indonesia, 2018).

Bantuan militer Arab Saudi ke Yaman tidak hanya dikirim secara langsung ke Yaman, namun juga bersiaga di perbatasan antara Arab Saudi dan negara bagian Yaman yang dikuasai oleh Houthi. Salah satunya adalah M2 Bradley kendaraan tempur infanteri M2 adalah sebagai wahana pengangkut infanteri di medan perang, menyediakan tembakan perlindungan bagi pasukan yang diturunkan dan menekan tank serta kendaraan tempur musuh. M2 Bradley memiliki tiga personel, komandan, penembak dan pengemudi, ditambah enam orang pasukan infanteri bersenjata lengkap. Pada September 2018 perbatasan SaudiYaman, tepatnya di ujung selatan wilayah Najran, Jizan dan Asir, Houthi yang berbasis di 
Yaman mengklaim telah menghancurkan kendaraan tempur infanteri M2 Bradley milik Angkatan Darat Arab Saudi di provinsi Najran, dengan menggunakan rudal modern buatan Iran.

Tidak hanya itu saja, memasuki 2019 banyak dari peralatan tempur Arab Saudi yang berada di perbatasan antara Arab Saudi dan Yaman beberapa yaitu, 4 kendaraan tempur tank dan 3 unit Oshkosh M-ATV buatan AS yang hancul atas serangan Houthi yang digunakan untuk mengamankan provinsi Najran pada Juli 2019. Dibulan dan tahun yang sama kemudian, militer Arab Saudi di Yaman bergerak untuk mengamankan dua pelabuhan di Laut Merah dan Selat Bab al-Mandeb setelah sekutu utamanya, Uni Emirat Arab (UEA), menarikan sebagian pasukannya dari Yaman. Perwira Saudi mengambil alih komando pangkalan militer di pelabuhan al-Mokha dan al-Khokha, yang sebelumnya digunakan pasukan UEA untuk mendukung serangan mereka di Hodeidah di dekatnya dan untuk memantau garis pantai (Muhammad, 2019).

Hingga terakhir pada 20 September 2019, koalisi yang dipimpin Arab Saudi melakukan operasi militer ke kota pelabuhan utara Yaman dan menghancurkan sekitar empat situs Hodeidah yang digunakan untuk merakit kapal dan ranjau laut kendali jarak jauh. Arab Saudi beralasan operasi ini bertujuan untuk mengamankan navigasi maritim di wilayah tersebut. Dan kelompok Al - Houthi menyebut bahwa koalisi Arab Saudi telah melanggar kesepakatan PBB di Swedia (Perdana, 2019).

\section{Kepentingan Arab Saudi}

\section{a. Keamanan Perbatasan}

Perbatasan secara sederhana dapat diartikan sebagai salah satu unit legal-politis yang memiliki fungsi unik dan strategis bagi suatu negara. Bagi setiap negara berdaulat, perbatasan memiliki fungsi-fungsi yang sangat berpengaruh bagi negaranya, diantaranya fungsi sebagai:

I. Militer - strategis, dimana perbatasan memiliki fungsi untuk memenuhi kebutuhan militer strategis suatu negara dalam pembangunan sistem pertahanan darat, laut dan udara untuk menjaga diri dari ancaman dari luar.

II. Konstitutif, yaitu didasari dari konsep hukum internasional modern suatu negara berdaulat wajib memiliki wilayah perbatasan yang didefinisikan dengan jelas. Yang artinya, perbatasan menetapkan posisi konstitutif suatu negara tertentu 
didalam komunitas internasional. Suatu negara memiliki kedaulatan penuh atas wilayah yang merupakan teritorinya.

III. Ekonomis, dimana perbatasan memiliki fungsi dimana batas wilayah suatu negara dapat melakukan kontrol terhadap pergerakan atau pengiriman barang antar-negara, perdagangan antar-negara, dan investasi asing serta menetukan batas eksplorasi kekayaan alam secara legal.

IV. Identitas dan persatuan nasional, yaitu pengikatan secara emosional terhadap komunitas yang ada atau berada dalam teritori tertentu. Baik itu berupa kesamaan pengalaman dan sejarah secara langsung ataupun tidak langsung untuk mengklaim secara emosional identitas dan wilayah tertentu.

V. Pembangunan negara-bangsa, perbatasan memberikan gambaran bagi negara untuk menentukan bagaimana dibentuknya sejarah sebuah bangsa, sebagai penentu jenis-jenis simbol-simbol yang dapat diterima secara luas, dan menentukan norma dan kultural secara bersama.

VI. Pencapaian kepentingan domestik, yaitu untuk mencapai kepentingan nasional dalam berbagai bidang dan menetukan batasan negara melakukan upayanya untuk mencapai kepentingan tersebut secara batas geografis (Wuryandari, 2009).

Maka dari itu, Arab Saudi merasa dituntut untuk melindungi perbatasan, menumbuhkan rasa aman bagi negaranya. Apabila dirasa ancaman dari luar akan mempengaruhi tidak hanya wilayah tapi kepentingan secara domestik negaranya. Sekitar $1.460 \mathrm{~km}$ panjang perbatasan Arab Saudi dan Yaman yang disepakati dalam Traktat Jeddah membuat Arab Saudi bekerja ekstra untuk melindungi kedaulatannya. Ancaman, imigran, penyelundupan dan terorisme menjadi konsen.

Lintas ilegal di daerah perbatasan Arab Saudi dan Yaman yang dilakukan oleh warga Yaman mengakibatkan banyaknya jumlah pekerja illegal yang masuk ke Arab Saudi meski telah berkali-kali melakukan deportasi, setidaknya ada 1,5 juta pekerja illegal dideportasi pada 2013 dan pada 2015 sekitar 800.000 ribu pekerja illegal di deportasi. Perang berkepanjangan mengakibatkan ketidakstabilan nasional dengan dua kubu yang ingin berkuasa di Yaman. Jika Yaman dikuasai oleh Al-Houthi dimasa depan, bukan tidak mungkin masalah imigran illegal ini semakin buruk diakibatkan ketidak sesuaian antara pemerintah Arab Saudi dan kaum Syiah (Knipp, 2016). 
Sebagai kawasan yang rentan, sepanjang jalur perbatasan antara Arab Saudi dan Yaman juga sering menjadi sasaran lalu lintas penyelundupan obat bius, narkoba, penyelundupan senjata dan perdagangan manusia ke wilayah Saudi. Para penyelundup tersebut bukanlah sepenuhnya berasal dari Yaman, negara Afrika seperti Ethiopia adalah salah satu sumbernya. Dalam situasi politik yang lemah, pemerintah Yaman menghadapi tantangan serius untuk memerangi perdagangan manusia, termasuk ancaman keamanan internal yang substansial, kontrol wilayah yang terbatas, dan kemampuan penegakan hukum menjadi sangat buruk.

Ancaman terorisme menjadi hal yang menakutkan, runtuhnya lembaga-lembaga pemerintah didalam tiga tahun perang telah menciptakan celah bagi AQAP dan ISIS untuk merekrut dan bahkan mengendalikan wilayah. Paham Syiah merupakan hal yang harus dihilangkan bagi Arab Saudi. Al-Houthi telah menjadi ancaman di sepanjang perbatasan selatan Arab Saudi, dengan menyusup melalui jalur bawah tanah yang melintasi wilayah gurun dan menembus wilayah udara Saudi dengan rudal Scud dan drone tanpa awak. Saudi terancam dari segi pertahanan udara dan infiltrasi darat dari seberang perbatasan di Yaman.

Dalam memberikan batuan militer ini sebetulnya Arab Saudi tidak sendiri, negara Teluk lainnya menjadi aliansi. Bagi Morgenthau kepentingan nasional melupakan hal terpenting karena hal tersebut yang mendahului sebelum kepentingan regional. Maka dari itu, memiliki aliansi haruslah yang memiliki manfaat yang berlandaskan keuntungan dan keamanan timbal-balik bagi negara peserta bukan pada ikatan-ikatan ideologis atau moral. Negara terlibat dalam suatu aliansi berdasarkan perhitungan, suatu negara tidak ingin ada kekuatan besar lain yang mengamcam negara mereka. Dalam pembentukan aliansi pasti akan timbul aliansi tandingan, secara kalkulasi rasional akan mendorong negara-negara untuk membentuk koalisi dengan negara-negara yang terancam oleh kekuaan yang dirasa lebih besar, bukan hanya kehendak untuk membantu negara yang lebih lemah, tetapi karena kelemahan negara yang terancam akan menjadi ancaman bagi negara-negara yang tidak terlibat dalam sengketa dan akan berefek bagi negaranya dari satu negara agresif dengan ambisi hegemonik (Mas'oed M. , 1989).

Maka dari itu kepetingan keamanan perbatasan Arab Saudi melalui bantuan milter untuk melindungi kedaulatannya dari ancaman, imigran asing, penyelundupan dan terorisme dan jika Presiden Hadi berhasil mengukuhkan kembali pemerintahannya di Yaman hal tersebut akan mempermudah mengatur permasalahan dan lobi diperbatasan. 


\section{b. Politik Ideologi}

Arab Saudi menggunakan pendekatan ideologi untuk memperluas pengaruhnya. Salah satunya aliansi dengan negara Teluk dalam Gulf Countries Cooperation (GCC) yang berisikan 6 negara, yaitu Arab Saudi, Kuwait, Bahrain, Oman, Qatar, dan Uni Emirat Arab yang semuanya memiliki pemerintahan berbentuk Monarki. Hal tersebut dapat dinilai cukup berhasil dalam memperluas pengaruhnya di kawasan. Dan peraktik seperti ini yang telah terjadi di Yaman. Iran dengan membangun jejaring untuk menguatkan legitimasi Syiah Houthi di Yaman. Sebaliknya Arab Saudi mencoba membantu kelompok Presiden Hadi untuk menguatkan Sunni di Yaman. Demikian pula keberhasilan hubungan antara Iran dengan Suriah yang dibangun berdasarkan kesamaan Ideologi dan kerja sama strategis antar negara. Efektifitas strategi tersebut yang dimainkan oleh kedua negara berbeda antara satu dengan yang lainnya dalam beberapa kasus.

Pada kasus Yaman, pemerintah Riyadh turun langsung melalui bantuan militer terhadap krisis yang terjadi di Yaman untuk menumpas kelompok Houthi di Yaman. Jika dilihat secara demografis, sebanyak 35\% penduduk Yaman memiliki pemahaman Syiah, hal tersebut dapat menjadi sebuah faktor yang mudah bagi kelompok seperti Al-Houthi untuk mempengaruhi dan membangun kekuatan untuk mengancam ideologi Sunni yang dipertahankan Arab Saudi.

Jika dilihat dari sisi sejarah, Iran memiliki bentuk Islam yang lebih revolusioner dan pemimpin revolusi tahun 1979 yaitu Ayatollah Khomeini yang memandang monarki tidak sesuai dengan Islam. Hal tersebutlah yang menjadi dorongan bagi Arab Saudi untuk terlibat dalam perang saudara di Yaman dengan bantuan militer. Jika terjadi demokratisasi di Yaman dan Houthi serta Iran terlibat didalamnya, hal tersebut akan mengancam eksistensi Arab Saudi. Mengingat paham Sunni Arab Saudi yang sangat anti terhadap Syiah.

Selain itu, Iran merupakan negara yang digadangkan akan membangun fasilitas senjata program nuklir, hal tersebut memunculkan kekhawatiran bagi Saudi, dan jika hal tersebut trealisasikan tentunya akan mengancam stabilitas keamanan dan hegemmoni Arab Saudi di Timur Tengah. Maka dari itu, keterlibatan Arab Saudi dengan bantuan militer didorong juga oleh motif politik, yaitu bertujuan untuk menahan hegemoni politik dari Iran dikawasan Timur Tengah. 


\section{c. Ekonomi}

Bantuan militer Arab Saudi ke Yaman memiliki kepentingan ekonomi, khususnya pada minyak dan gas. Berdasarkan dari salah satu kategori kepentingan nasional economic wellbeing, atau dapat disebut kesejahteraan ekonomi, sektor ekonomi harus selalu dijamin kesetabilannya oleh pemerintah agar tercipta kesehjateraan di negara tersebut. Perusahaan minyak Saudi Aramco mengalami penyerangan pada September 2019. Hal tersebut mengakibatkan mengurangnya produksi minyak dunia dari perusahaan tersebut. Seperti yang kita ketahui, dunia memiliki jatah harian sebanyak 85 juta barel minyak dari lebih dari 4.000 ladang setiap harinya. Beberapa hasil minyak Arab Saudi yang sangat berpengaruh adalah Ladang minyak Ghawar, di Arab Saudi, menempati urutan pertama lebih dari 100 miliar barel minyak sebagai penopang minyak dunia. Kemuadian ladang Shaybah 750.000 barel per hari menmpati posisi 2 menurut laman Forbes. Namun, ladang tersebut telah memasuki masa senja, dengan produksi minyak yang mulai mengurang (Helman, 2010).

Perang saudara di Yaman telah mengakibatkan lumpuhnya sistem ekonomi di Yaman. Ketegangan regional antara Arab Saudi yang mendukung kelompok Presiden Hadi dengan Al-Houthi yang didukung oleh Iran telah membuat selat Hormuz menjadi rute yang tidak dapat diandalkan untuk 30 persen pasokan minyak dunia dan alternatif pelabuhan transshipment dan pipa yang merupakan komponen vital dari stabilitas ekonomi masa depan Arab Saudi menjadi alasan utama (Orkaby, 2019).

Namun pada kenyataannya, Al-Houthi menjadi lawan yang sangat mengancam bagi Arab Saudi. Serangan sebanyak 10 drone atau pesawat tanpa awak di ladang minyak Khurais di Saudi Arabia September 2019 adalah bukti, milisi kelompok Houthi mampu menyerang ke wilayah Saudi dan mengganggu pasokan minyak global, merugikan monarki dengan jumlah miliaran dolar akibat kerusakan dan kehilangan pendapatan. Hal tersebut mengakibatkan berkurangnya pasokan minyak global sebanyak 5\% dan harga minyak melonjak tinggi.

Ada beberapa pilihan jika Arab Saudi tidak mampu memegang kendali atas keamanan selat Hormuz, yaitu melanjutkan pembangunan pipa melalui al-Mahra, provinsi paling timur Yaman. Pembangunan saluran pipa ini dan pelabuhan Nishtoon di pantai selatan Yaman adalah puncak dari dua dekade negosiasi Saudi dan upaya diplomatik. Arab Saudi menginginkan pemberian izin penyewaan tanah untuk pipa ini, namun mantan presiden Yaman Ali Abdullah Saleh telah menolak untuk memberikan kedaulatan Arab Saudi atas 
koridor teritorial yang diperlukan untuk membangun dan memantau pipa ini. Ketegangan dengan Al-Houthi dan Iran dan ketidakpastian dari lalu lintas di selat Hormuz sebagai jalan untuk pasokan minyak Saudi telah menambah tekanan pada monarki Saudi untuk mencari alternatif pengiriman.

Pada tahun 2013, Arab Saudi memiliki Petroline sepanjang 746 mil, yang sering disebut juga dengan nama East-West Pipeline, yang melintasi jalur Arab Saudi dari kompleks Abqaiq ke Laut Merah. Sistem Petroline terdiri dari dua jalur pipa dengan kapasitas maksimum 4,8 juta barel perhari. Jalur pipa sebesar 56 inci berkapasitas 3 juta barel perhari, yang pada saat ini mampu mengangkut sekitar 2 juta barel perhari. Dalam beberapa tahun terakhir jalur pipa sebesar 48 inci telah beroperasi sebagai pipa gas alam, yang kemudian oleh Arab Saudi dialihfungsikan menjadi pipa minyak. Alih fungsi ini meningkatkan kapasitas pipa minyak sisa Arab Saudi untuk menghindari Selat Hormuz dari 1 juta barel perhari ke 2,8 juta barel perhari, tetapi hal ini baru dapat dicapai apabila sistem tersebut beroperasi dengan kapasitas maksimum. Arab Saudi juga mengoperasikan jalur pipa gas alam cair Abqaiq-Yanbu dengan kapasitas 290.000 barel perhari. Akan tetapi, pipa ini sekarang beroperasi dengan kapasitas penuh dan tidak dapat beralih fungsi menjadi pipa minyak (Priambodo, 2017).

Arab Saudi memberikan batuan militer pada kelompok Hadi di Yaman untuk mempertahankan dan mendapatkan kembali keamanan lalu lintas di selat Hormuz. Jalur alternatif bagi Selat Hormuz yaitu pipa minyak secara tidak sengaja menciptakan ancaman keamanan baru terhadap fasilitas minyak. Jika pipa minyak al-Mahra selesai dibangun, pasukan keamanan Saudi akan mewarisi ratusan mil dari target drone potensial yang melewati wilayah asing yang berpotensi konflik. Pembayaran sewa, dalam bentuk suap kepada para pemimpin suku setempat, akan mahal, demikian pula logistik pemantauan wilayah udara di sekitar pipa. Tanggung jawab utama untuk mengamankan jaringan pipa ini dan fasilitas minyak lainnya tetap menjadi tanggung jawab Arab Saudi, sementara Amerika Serikat dan PBB hanya dapat menyediakan pencegahan dan pemantauan yang cukup untuk mencegah konflik regional yang lebih luas. Secara otomatis sebenarnya jalur selat Hormuz adalah jalur teraman bagi lalulintas minyak Arab Saudi.

Jika kekuasaan Al-houthi secara politik ataupun militer dapat diredam dan pemerintahan Presiden Hadi menjadi dominan, hal tersebut akan mempermudah Arab Saudi dalam mengontrol fasilitas minyaknya. Arab Saudi dapat dapat menekan hegemoni dari Iran yang 
menguasai selat Hormuz dan sekaligus mendapatkan kemudahan untuk melobi Presiden Hadi yang secara latar belakang tidak memiliki potensi untuk menentang pembangunan pipa tersebut jika pembangunan pipa minyak menjadi pilihan terakhir, karena alasan bantuanbantuan yang telah diberikan Arab Saudi untuk menguatkan posisi politik kekuasaannnya. Bantuan militer merupakan harapan Arab Saudi, investasi jangka panjang bagi keuntungan ekonominya di sekitar perbatasan.

\section{KESIMPULAN}

Bantuan militer Arab Saudi bermula pada Maret 2015 ketika Presiden Abduh Rabbuh Mansur Hadi meminta bantuan untuk memulihkan kekusasaannya di Yaman dengan mengirim surat kepada Arab Saudi dan Negara Teluk lainnya untuk melawan pasukan AlHouthi di Yaman. Arab Saudi menyetujui permintaan bantuan tersebut. Arab Saudi dan Negara Teluk lainnya mengirimkan pesawat tempur untuk melancarkan serangan udara kepada Al - Houthi dan sekutu yang mengancam akan menyerbu pelabuhan selatan Aden.

Didukung kekuatan militer yang baik, dukungan Arab Saudi tehadap kelompok Presiden Hadi sangat intens, bahkan dilansir melalui data Stockholm International Peace Research Institute, sejak tahun 2014 sampai dengan 2018 Arab Saudi menduduki peringkat pertama sebagai importir perdagangan senjata di dunia. Beberapa bantuan militer Arab Saudi sejak tahun 2015 hingga 2019 yaitu, 100 pesawat tempur dan 150.000 tentara untuk operasi militer pada Maret 2015, F15 pada April 2015, 10.000 pasukan dan 30 helikopter serang AH-64 Apache pada September 2015, jet tempur serta kapal perang pada 2018 untuk ditempatkan di Hudaidah, 4 kendaraan tempur tank dan 3 unit Oshkosh M-ATV buatan AS pada 2019 dan beberapa kendaraan pengangkut senjata militer lainnya.

Bantuan yang diberikan Arab Saudi bukanlah hanya sebagai motif kemanusiaan, melainkan ada kepentingan yang akan berdampak jangka panjang terhadap Arab Saudi kedepannya. Kepentingan tersebut antara lain, kepetingan keamanan perbatasan untuk melindungi kedaulatannya dari ancaman, imigran asing, penyelundupan dan terorisme dan mempermudah mengatur permasalahan diperbatasan. Yang kedua yaitu kepentingan politik ideologi, dimana paham Sunni dan Syiah terlibat didalamnya. Al-Houthi yang didukung Iran dengan pemahaman Syiah adalah ancaman besar bagi hegemoni Arab Saudi di Timur Tengah. Sehingga, dengan adanya aliansi bersama negara sekutu dengan satu pemahaman Sunni, Arab Saudi berusaha mempertahankan hegemoninya terutaman dikawasan Teluk dan Timur Tengah. Dan yang terakhir yaitu kepentingan ekonomi, melanjutkan pembangunan 
pipa melalui al-Mahra, provinsi paling timur Yaman sebagai alernatif pengiriman minyak, karena selat Hormuz yang sudah tidak lagi stabil dan aman karena dikuasai Iran untuk lalu lintas minyak bagi Arab Saudi.

\section{DAFTAR PUSTAKA}

Agestu, I. (2014, Oktober 01). Konflik Yaman : Apa yang Harus diketahui soal Al-Houthi. Retrieved from

CNN: https://www.cnnindonesia.com/internasional/20141001123601-120-4926/apa-yangharus-diketahui-soal-al-houthi

Asmardika, R. (2015, Maret 28). Kronologi Konflik Yaman Hingga Kini. Retrieved from OkNews: $\quad$ https://news.okezone.com/read/2015/03/28/18/1125649/kronologikonflik-yaman-hingga-kini

Chughtai, M. G. (2019, Mei 13). Saudi Arabia: The world's largest arms importer from 2014-2018. Retrieved from Aljazeera: https://www.aljazeera.com/indepth/interactive/2019/05/saudi-arabia-world-largestarms-importer-2014-2018-190512140945972.html

Cipto, B. (2011). Dunia Islam dan Masa depan Hubungan Internasional Abad 21. Yogyakarta: LP3M UMY.

CNN Indonesia. (2018, Juni 14). Serangan Terbesar Saudi di Yaman, Gempur Basis Utama Houthi . Retrieved from CNN Indonesia : https://www.cnnindonesia.com/internasional/20180614053110-120305986/serangan-terbesar-saudi-di-yaman-gempur-basis-utama-houthi

Cole, N. L. (2019, Juli 09). Theories of Ideology :The Concept and Its Relationship to Marxist Theory. Retrieved from ThoughtCo.com: https://www.thoughtco.com/ideology-definition-3026356

Dubley, D. (2018, Februari 26). The 10 Strongest Military Forces In The Middle East. Retrieved from Forbes: https://www.forbes.com/sites/dominicdudley/2018/02/26/ten-strongest-militaryforces-middle-east/\#648b52a316a2

Elzabar, S. (2012). Kamus Hubungan Internasional. Yogyakarta: Pustaka Utama.

Firdaus, H. M. (2017). Permintaan Bantuan Pemerintah Yaman Kepada Arab Saudi Dalam Penyelesaian Konflik di Yaman. Retrieved from UMY Repository: http://repository.umy.ac.id/handle/123456789/12141

Freeden, M. (2001). Ideology: Political Aspects. International Encyclopedia of the Social \& Behavioral Sciences, 7174-7177. 
Global Fire Power. (2019). Saudi Arabia Military Strength. Retrieved from Global Fire Power: https://www.globalfirepower.com/country-military-strengthdetail.asp?country_id=saudi-arabia

Hadiwinata, B. S. (2017). Studi dan Teori Hubungan Internasional : Arus utama, Alternatif, dan Reflektivitas. Jakarta: Yayasan Pustaka Obor Indonesia.

Hanna, S. A. (2015, Maret 26). Saudi Arabia launches airstrikes in Yemen. Retrieved from CNN News: https://edition.cnn.com/2015/03/25/middleeast/yemen-unrest/

Helman, C. (2010, Januari 21). The World's Biggest Oil Reserves . Retrieved from Forbes: https://www.forbes.com/2010/01/21/biggest-oil-fields-business-energy-oilfields.html\#24ef57312ab0

Jatmika, S. (2016). Skripsi : Metodologi dan Romantikanya. Yogyakarta: Penerbit Samudra Biru.

Jones, L. (2019). Intervention vs Nonintervention. Retrieved from Study.com: https://study.com/academy/lesson/intervention-vs-nonintervention-in-internationalrelations.html

Khaleejtimes.com. (2019). Saudi women can now join the armed forces . Dubai: khaleejtimes.com.

Kirkpatrick, M. M. (2015, Maret 25). Saudi Arabia Leads Air Assault in Yemen. Retrieved from The New York Times: https://www.nytimes.com/2015/03/26/world/middleeast/al-anad-air-base-houthisyemen.html

Knipp, K. (2016, Februari 2014). Arab Saudi Perketat Penjagaan Perbatasan. Retrieved from DW Made for Minds: https://www.dw.com/id/arab-saudi-perketat-penjagaanperbatasan/a-17410217

Mas'oed, M. (1989). Studi Hubungan Internasional. Yogyakarta: Pusat Antar Universitas UGM.

Mas'oed, M. (1990). Ilmu Hubungan Internasional : Disiplin dan Metodologi. Yogyakarta: LP3ES.

Muhammad. (2019, Juli 13). Pasukan Saudi Gantikan Posisi Pasukan UEA Yang Ditarik dari Yaman. Retrieved from liputanislam.com: http://liputanislam.com/internasional/timur-tengah/pasukan-saudi-gantikan-posisipasukan-uea-yang-ditarik-dari-yaman/

O'Callaghan, M. G. (2002). International Relation : The Key Concepts. London: Routledge.

Orkaby, A. (2019, Oktober 24). Saudi Arabia's War in Yemen Is About Oil. Retrieved from The National Interest: https://nationalinterest.org/blog/middle-east-watch/saudiarabia\%E2\%80\%99s-war-yemen-about-oil-90736 
ParsToday. (2018, Januari 06). Transformasi Yaman di Tahun 2017. Retrieved from ParsToday: $\quad$ https://parstoday.com/id/radio/middle_east-i49331transformasi_yaman_di_tahun_2017

Pearson, F. S. (1999). International Politic Economi: Conflict and Cooperation in The Global System. USA: McGraw - Hill College.

Perdana, A. V. (2019, September 20). Kilang Minyaknya Diserang, Koalisi Arab Saudi Lancarkan Operasi Militer ke Yaman. Retrieved from Kompas.com: https://internasional.kompas.com/read/2019/09/20/16273991/kilang-minyaknyadiserang-koalisi-arab-saudi-lancarkan-operasi-militer?page=all

Priambodo, S. (2017). Motif Intervensi Arab Saudi Terhadap Perang Saudara di Yaman. Fakultas Ilmu Sosial dan Ilmu Politik, Universitas Airlangga, 211.

Reuters. (2015, September 8). Number of Saudi-led coalition troops in Yemen 'rises to 10,000'. Retrieved from Arabian Business: https://www.arabianbusiness.com/number-of-saudi-led-coalition-troops-in-yemenrises-10-000--605525.html

Ronapea. (2016, November 21). Konsep Kepentingan Nasional dalam Hubungan Internasional. Retrieved from unair.ac.id: http://ronapeafisip16.web.unair.ac.id/artikel_detail-165107-JURNAL\%2520SOH\%2520101KONSEP\%2520KEPENTINGAN\%2520NASIONAL\%2520DALAM\%2520HUB UNGAN\%2520INTERNASIONAL.html

Saraswati, P. D. (2017, Desember 31). Pengamat: Alasan Saudi Intervensi Yaman Tak Bisa Diterima . $\quad$ Retrieved from CNN Indonesia: https://www.cnnindonesia.com/internasional/20171231085943-106265749/pengamat-alasan-saudi-intervensi-yaman-tak-bisa-diterima

Sugito. (2016). Organisasi Internasional: Aktor dan Instrumen dalam Hubungan Internasional. Yogyakarta: The Phinisi Press Yogyakarta.

Thompson, H. J. (1985). Politic Among Nation, The Struggle for Power and Peace (Sixth Edition). New York: Knopf:distributed by Random House.

Wijatmadja, A. d. (2016). Pengantar Ilmu Hubungan Internasional. Malang: Intrans Publishing.

Wuryandari, G. (2009). Pengelolaan Keamanan dan Perbatasan : Kajian Teoritis. In C. P. Genewati Wuryandari, Keamanan di Perbatasan Indonesia : Sumber Ancaman dan Kebijakan Pengelolaannya (pp. 36-37). Yogyakarta: Pustaka Pelajar.

Yani, A. B. (2014). Pengantar Ilmu Hubungan Internasional. Bandung: Remaja Rosdakarya. 